\title{
Hydraulic calculation of horizontal open drainages
}

\author{
Aybek Arifjanov, Maqsud Otaxonov", Luqmon Samiev and Shamshodbek Akmalov \\ Tashkent Institute of Irrigation and Agricultural Mechanization Engineers, Hydraulic Department, \\ 100000 M.Ulugbek str. 39, Tashkent, Uzbekistan
}

\begin{abstract}
In article analysed the factors influencing the hydraulic processes which arise in the open horizontal drainage systems. Open drainages plays important role in order to improve the ameliorative condition of the agricultural area, salt washing on the soil. It is emphasized that the deep drainage in our region has a good effect on the soil condition and salt removing. At present, efforts are being made to improve the productivity of the collectors to clean and built. As example the collector drainage systems in Syrdarya region are listed. It is observed that the motion mode of open drainage flows is physically identical. Due to the complexity of equations in the unstable motion mode, the drainage water flow scheme in the collectors reflects the hydraulic calculation of the movement. Researches were provided in open agricultural drainage system of Syrdarya region and analysis have been done in natural field conditions. It has been noted when slope of the drainage bed is equal to $i<0,0005$ intensity of deformation were very high, when slope was between $0,0005<i<0,0011$ intensity of deformation of collector bed was equal to the minimum level. In this article provided hydraulic calculation for Syrdarya region drainage system for choosing dynamical stable shape of bed. Those hydraulic calculations and projections ensure collectors with long time period of exploitation condition. Calculation and analyses were done with taking account trapezoidal capacity of the stream in drainage system, and the results of studies on increasing the flow efficiency are reflected. Analysed that when slope will increase until $20 \%$ discharge capacity will increase because of high average flow velocity increased by 7-8 times and discussed difference of them. As a result of the hydraulic calculation, the slope of the drainage increased from i- 0,00048 to $\mathrm{i}-0,0006$, the fact that the flow capacity increased by $25 \%$ due to the increase because of flow velocity.
\end{abstract}

\section{Introduction}

From the very ancient times, farmers have been working on against to water salinization, fertility degradation, and cleaning of soils from harmful salts with water. In the past, the issue of removing wastewater from the cultivated fields through artificial collector drainage

\footnotetext{
* Corresponding author: maqsudxon.otaxonov.87@mail.ru
} 
networks was main considered aim. Later, in 1929-1931, drainages started widely used expat removing salt from soils, for against to salinization of soil again and cultivation of those lands. The open drainages began to be drilled deeper on the basis of certain hydraulic calculations, and it start to give high results.

In many years of experience of different researchers it has been established that deep drainage systems allow to quickly and safely remove salts of soils, reduce underground water level to the required level [1-3].

The quality and quantity of the crop yields are primarily dependent on land reclamation, with the aim of improving land reclamation, achieving high yields, improving the quality of the products, were widely provides salt washing activities by farms. It starts to be complicate to do agricultural activities without doing salt washing activities. At the same time, it is necessary to bring out from agricultural field salt washing water and saline water produced after irrigation, with this aim were built artificial drainage systems $[4,5,6]$. As it is known, the main task in the process of salt removing is to dissolution salts in the soil with water and to remove them from the agricultural area. For this purpose, it is necessary to ensure effective exploitation of drainage system. For this purpose, in our country new state programs have been developed and realized for to further improve the ameliorative condition of irrigated lands and salt washing in it, repair and rehabilitate drainage systems and to construct new systems in order to prevent salinization and boggling [7,8]. The total length of the drainage system of Syrdarya region is $16,189.8 \mathrm{~km}$, of which $7479.13 \mathrm{~km}$ is open, $8709.87 \mathrm{~km}$ is closed-type drainage system. Main drainage systems of the region are Central Mirzachul, Shuruzak, Bayovut, Yettisay, Sardoba and Railway collectors. The longest main drainage system is Mirzachul collector, with the length of $84.70 \mathrm{~km}$. In Syrdarya region during a year provides cleaning and repairing of collector drainage systems with the length from 950 to $1100 \mathrm{~km}$ [9].

\section{Methods and materials}

In the research and in analysis, were used analytical and experimental methods and also used mathematical and statistical methods of hydraulics and hydrology.

Investigations were conducted in the drainage systems of Khovos and Sayhunobod districts of Syrdarya region with the aim of study the dynamic change processes in the open drainage system. Studies in natural field conditions have allowed to ensure the dynamical stability of the open horizontal drainage system and their connection with the hydraulic flow parameters.

\section{Results}

The results of field experiments are shown in Figures 1,2,3.

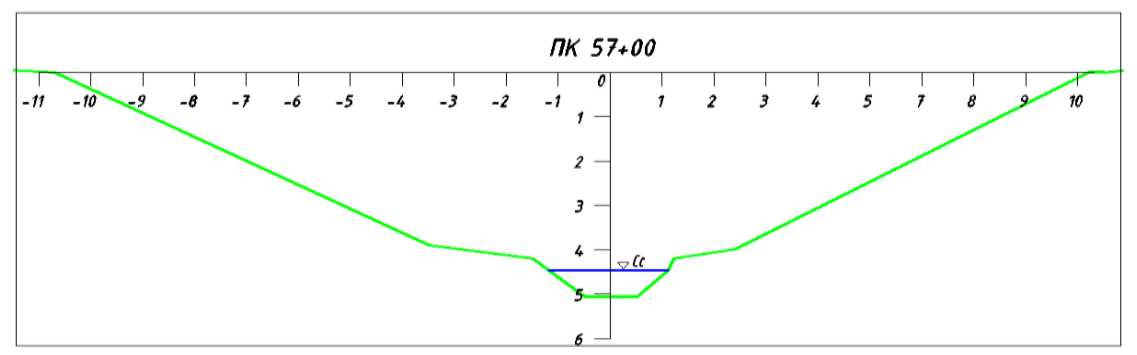

Fig. 1. Cross section of open drainage $\mathrm{PC} 15+00$ 


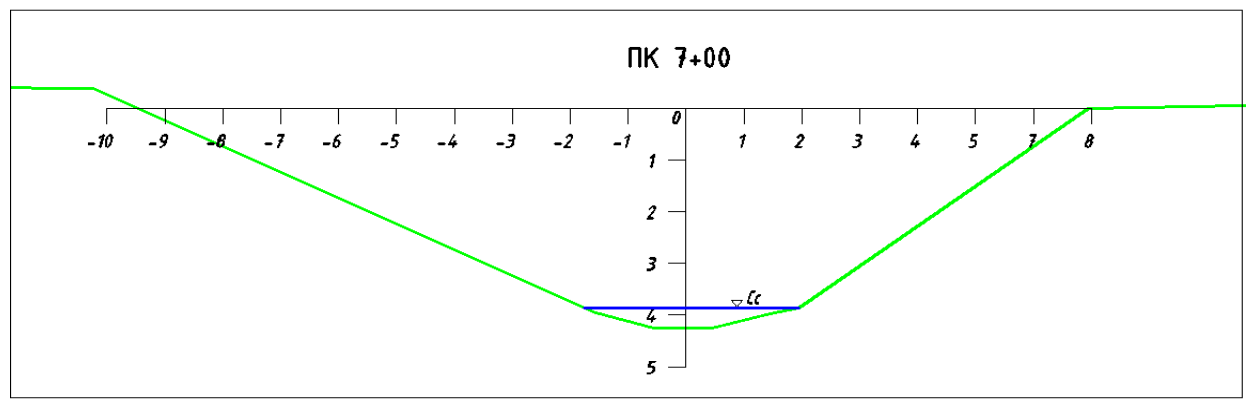

Fig. 2. Cross section of open drainage $\mathrm{PC} 7+00$

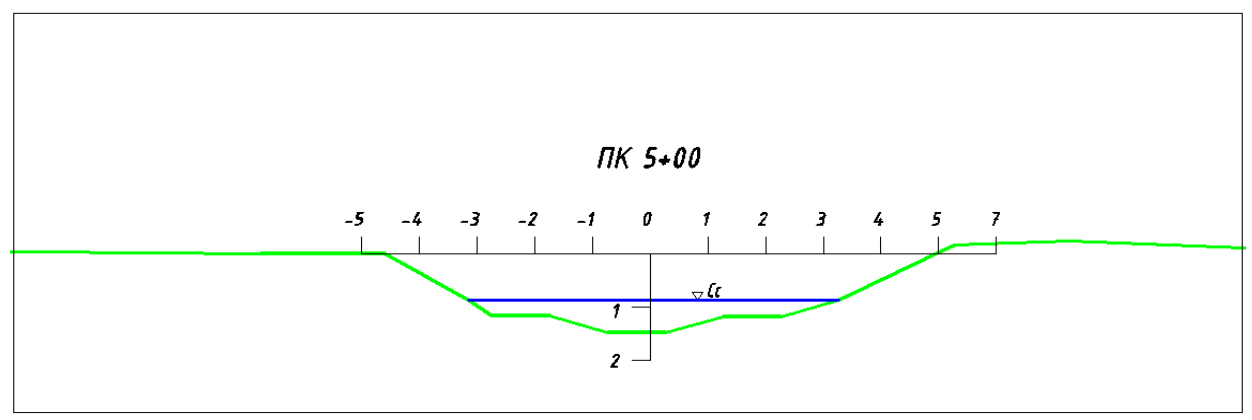

Fig. 3. Cross section of open drainage PC $5+00$

Studies have shown that the drainage lines which constructed at $\mathrm{i}<0,0005$ has property to fill with sediments very fast. Effective slope of the drainage system were found to be $0,0005<\mathrm{i}<0,0011$. Figure 1 shows the soil washing of the open bed drainage system with the name of $2 \mathrm{~K}-4$. As a result, the depth of the collector has been increasing over the years. It is impossible to do cleaning activities in these collector. The collector at the Figure 2 with the name of SK-2-4 operates normally, but also can be seen few washing situation in it. In the drainage which called VSh-20A in Figure 3, the depth has risen significantly above the depth of the projection and deterioration of efficiency because of the sedimentation. In the change of the bed of all drainages the flow velocity playes important role in the changes in it bed drain. Hydraulic parameters of water flow in drainage are shown in Table 1 below.

Table 1. Hydraulic parameters of the drainage

\begin{tabular}{|c|c|c|c|c|c|}
\hline $\begin{array}{c}\text { Name of } \\
\text { open } \\
\text { drainage }\end{array}$ & $\begin{array}{c}\text { Depth of the } \\
\text { flow, } \mathrm{m}\end{array}$ & Slope & $\begin{array}{c}\text { Cros section, } \\
\mathrm{m}^{2}\end{array}$ & $\begin{array}{c}\text { Avarage } \\
\text { velocity of } \\
\text { the flow, } \mathrm{m} / \mathrm{s}\end{array}$ & $\begin{array}{c}\text { Flow } \\
\text { discharge, } \\
\mathrm{m}^{3} / \mathrm{s}\end{array}$ \\
\hline 2-K-4 & 0,6 & 0,0047 & 1 & 1,16 & 1,16 \\
\hline SK-2-4 & 0,4 & 0,0011 & 0,94 & 0,43 & 0,41 \\
\hline VSH-20A & 0,6 & 0,0003 & 2,33 & 0,28 & 0,67 \\
\hline
\end{tabular}

Summarizing the results of the researches on can say, with the aim of to increase efficiency and dynamic stability of the drainage systems were provided hydraulic calculations of open drainage in Syrdarya region. Hydraulic calculations were conducted with increasing slope of the drainage system until $20 \%$, i.e. $i=0,00048$ until $i=0,0006$. Measured average flow velocity in $\mathrm{i}=0,00048$, in this situation average speed of the flow is equal to $\mathrm{v}=0,25 \mathrm{~m} / \mathrm{s}$, in the second condition measured average flow speed in condition of $i=0,0006$, average flow 


\section{FORM-2019}

velocity is equal to $\mathrm{v}=0,27 \mathrm{~m} / \mathrm{s}$. In both situation in case of analysing dynamic stability of the collector, determined sediment transportation property of the flow. The distribution potential of the sediment particles, $\mathrm{d}=0.04-0.275 \mathrm{~mm}$, and the difference between them are shown in the following table and figure (Table 2, Figure 4).

Table 2. Permeability and displacement of flow in open drainage beds.

\begin{tabular}{|c|c|c|c|c|}
\hline $\mathrm{d}, \mathrm{mm}$ & $\mathrm{W}, \mathrm{mm} / \mathrm{s}$ & $\mathrm{S} 1$ & $\mathrm{~S} 2$ & $\Delta \mathrm{S}, \%$ \\
\hline 0,04 & 1,11 & 3,582 & 4,750 & 25 \\
\hline 0,05 & 1,73 & 2,057 & 2,728 & 25 \\
\hline 0,06 & 2,49 & 1,305 & 1,730 & 25 \\
\hline 0,07 & 3,39 & 0,887 & 1,177 & 25 \\
\hline 0,08 & 4,43 & 0,635 & 0,842 & 25 \\
\hline 0,09 & 5,61 & 0,473 & 0,627 & 25 \\
\hline 0,1 & 6,92 & 0,364 & 0,482 & 25 \\
\hline 0,125 & 10,81 & 0,208 & 0,276 & 25 \\
\hline 0,15 & 15,6 & 0,132 & 0,175 & 25 \\
\hline 0,175 & 18,9 & 0,104 & 0,137 & 25 \\
\hline 0,2 & 21,6 & 0,088 & 0,116 & 25 \\
\hline 0,225 & 24,3 & 0,076 & 0,100 & 25 \\
\hline 0,25 & 27 & 0,066 & 0,088 & 25 \\
\hline 0,275 & 29,9 & 0,058 & 0,077 & 25 \\
\hline
\end{tabular}

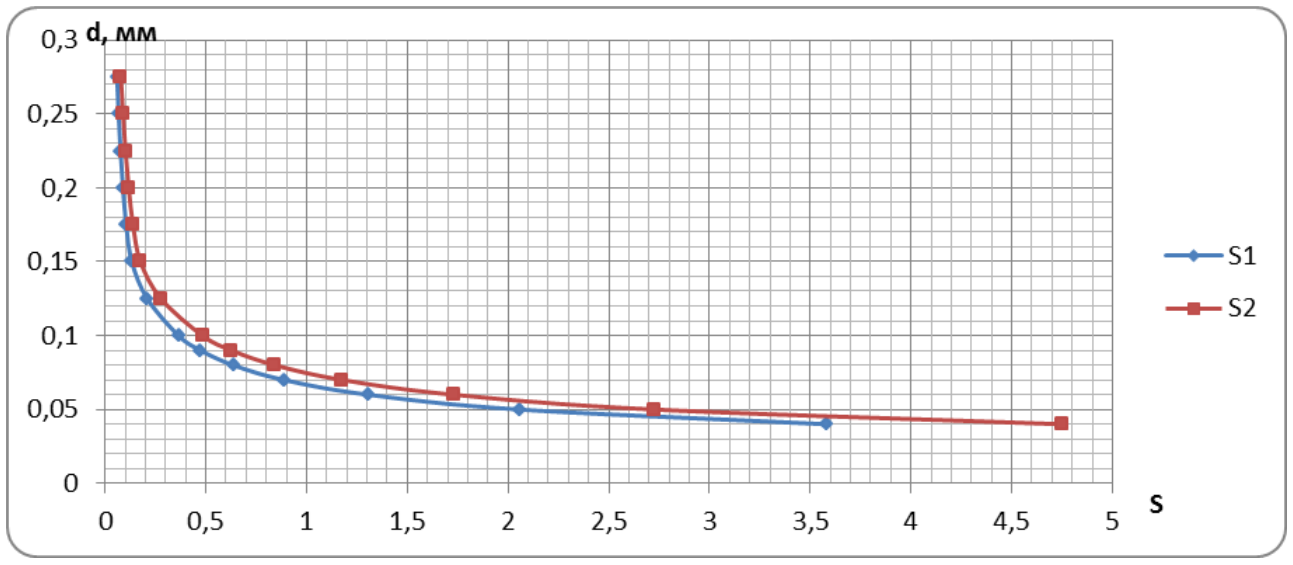

Fig. 4. Flow capacity of open horizontal flow

As shown in the Table and figure, on can see that the current flow strength increases by 25 percent in the design of the second.

\section{Discussions}

At present, the first task of projection of open drainages is to carry out accurately the hydraulic calculations to ensure efficient operation for a long period of time, and then calculate construction costs based on the specified hydraulic parameters. The hydraulic calculations provides primarily due to the effects of atmospheric precipitation, wind and filtration erosion on the drainage bed by the sand and soil particles, the drainage water leakage, ie the sludge drainage and the increase in water velocity in the collector, it must not be avoided, that is, the condition of washing [10-12]. 


$$
\vartheta_{1}<\vartheta_{\mathrm{z}}<\vartheta_{\mathrm{y}}
$$

there $\vartheta_{\mathrm{l}}$-flow velocity which ensure unsedimentation;

$\vartheta_{\mathrm{z}}$ - flow rate in drainage;

$\vartheta_{\mathrm{y}}$-nonwashing velocity of drainage.

The cross-sectional shape of the drainages and channels projected in our country is primarily in the form of a trapezoidal, and the following parameters should be used to determine the flow hydraulic elements (Fig. 5).

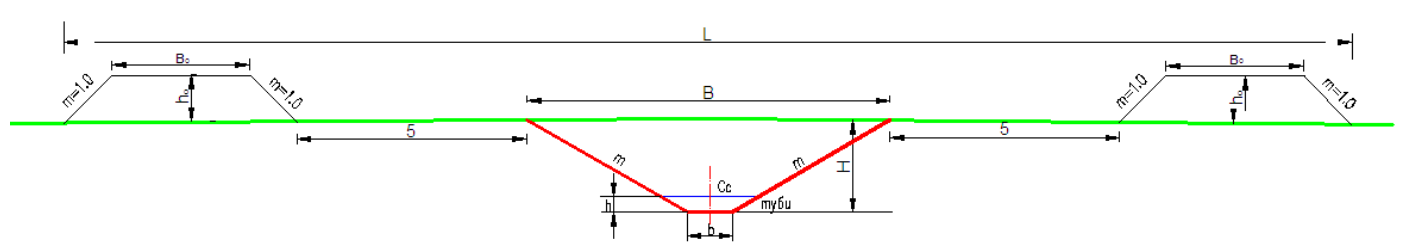

Fig. 5. Cross-section of open horizontal drainage

b- width (bottom) of drainage;

B- width (by water surface) of drainage;

$\mathrm{h}$ - depth of water in drainage;

$\mathrm{m}$ - slope coefficient of drainage,

To date, in the projection of the drainage system, main attention gives to the water intake and changes of depth, the uneven movement regime, and the speed and velocity of the dripping surface of the dripping can vary according to the water supply. This issue of hydraulic computing is still actual. During calculation of the velocity and depth of the stream is conditional on a smooth motion and is determined by the Shezi formula [13-15]. It should be noted that the physical conditions of the flow movement in the open drainage are quite complicated in terms of the smooth movement conditions.

Let's take a look at the calculation discharge based on Shezi formula:

$$
Q=\omega \cdot C \sqrt{R \cdot i}
$$

there: $\quad \omega=(\mathrm{b}+\mathrm{mh}) \mathrm{h}-$ cross-section of movement, $\mathrm{m}^{2}$;

C- coefficient Shezi, $\mathrm{m}^{0,5} / \mathrm{s}$;

$\mathrm{R}=\omega / \chi$ - hydraulic radius, $\mathrm{m}$;

$\chi=\mathrm{b}+2 \mathrm{~h}\left(\mathrm{~m}^{2}+1\right)^{1 / 2}-$ watered perimeter;

$\mathrm{i}$ - slope of the drainage bottom.

In the open drainages, the width of the riverbed is at least $b=1 \mathrm{~m}$. Let's look at the hydraulic calculus of the $19 \mathrm{~K}-7-2 \mathrm{~A}$ open drainage, which is $1400 \mathrm{~m}$ in length. In the projection its water discharge was $0.1 \mathrm{~m} 3 / \mathrm{s}$, the width of the bottom $\mathrm{b}=1 \mathrm{~m}$, the incidence $\mathrm{i}=0,00048$, the slope coefficient is obtained from QM and Q [16] according to the soil type it equal to $m=1,75$, Hydraulic calculations were carried out taking into account 0.03 . As a result, the water velocity was estimated at $\mathrm{v}=0.25 \mathrm{~m} / \mathrm{s}$ and water depth $\mathrm{h}=0.28 \mathrm{~m}$. The table below shows the result of hydraulic calculation of the open drainage which is projected.

\begin{tabular}{|c|c|c|c|c|c|c|c|c|c|c|}
\hline \multirow{2}{*}{ 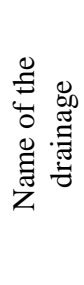 } & \multicolumn{2}{|r|}{$\begin{array}{l}\stackrel{\mathbb{J}}{Z} \\
\end{array}$} & 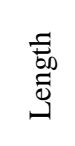 & 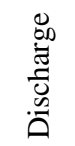 & 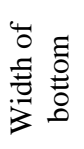 & $\frac{\ddot{\alpha}}{\tilde{\sigma}}$ & 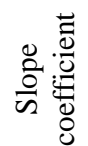 & 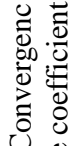 & 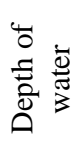 & 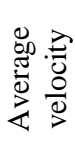 \\
\hline & $\begin{array}{l}\text { Beginn } \\
\text { ing of } \\
\text { PC }\end{array}$ & End of PC & $\mathrm{L}, \mathrm{m}$ & $\begin{array}{c}\mathrm{Q}, \\
\mathrm{m}^{3} / \mathrm{s}\end{array}$ & $\mathrm{b}, \mathrm{m}$ & $\mathrm{i}$ & $\mathrm{m}$ & $\mathrm{n}$ & $\mathrm{h}$ & $\vartheta$ \\
\hline
\end{tabular}

Table 3. Hydraulic elements of open horizontal drainage. 


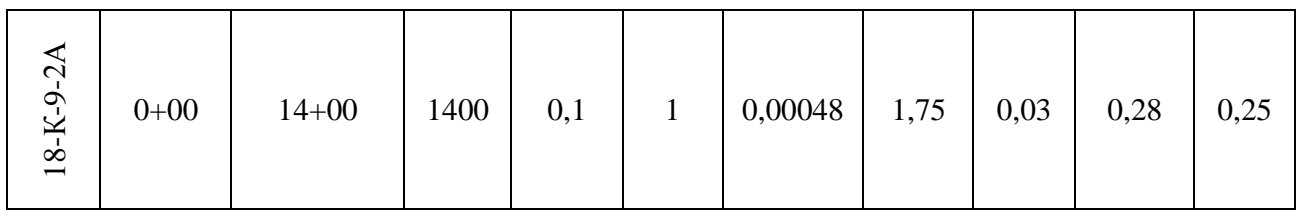

The above results show that the water velocity in the drainage is considerably low, and it can let to fill collectors with sediments as a result of drowning of water induced by sand and soil particles, water filtration erosion and other factors caused by natural and artificial factors. As a result, time by time the shape of the bed changes rapidly, the water flow rate decreases, the surface water level rises, the drainage efficiency decreases, and the shortest possible time to perform mechanical cleaning or repair work. The effective solution of this problem is projection collectors based on hydraulic rules and calculations. The solution is to offer the following tasks: From the hydraulic perspective, it is necessary to increase the flow velocity for removing the sediment from the water.

As is well-known in the scientific works provided in this destination [17,18], the sediment transportation property of flow depends on several factors. From those factor we will consider the flow velocity controlling problem. The flow of the stream can be achieved by increasing the drainage rate. The water velocity in open drainage can be substantially reduced by the cross-sectional surface and inclination of the stream, which can significantly reduce the time and costs of construction of collectors by increasing the water velocity, decreasing the cross-sectional surface.

For certain $\mathrm{Q}, \mathrm{m}, \mathrm{n}$, i, we can construct several sections of the optional dimension with different $b$ and motion sections. In these cross-sections there should be such a variant that the average velocity of the flow is very high, the surface of the cross-section of the $\vartheta_{\text {мах }}$ channel cross-section surface is the smallest, ie $\omega_{\min }$. When this condition is met, such cross-sectional are referred as the most hydraulics suitable part [19,20]. The following scenarios can be achieved by removing the above negative effects by increasing flow velocity.

From the hydraulic point of view, on can describe the density of the drain core as follows $[20,21]$ :

$$
b_{2}=A Q^{x}=1,4 \cdot 0,1^{0,85}=0,2 m
$$

there: $\quad b_{2}$-width of collector bottom, m;

$A$ - coefficient of Grishkan;

$\mathrm{Q}$ - discharge, $\mathrm{m}^{3} / \mathrm{s}$;

$\mathrm{X}$-degree index.

According to Consistency condition: $\mathrm{Q}<1,5 \mathrm{~m}^{3} / \mathrm{s}$, then $\mathrm{A}=1,4 ; \quad \mathrm{x}=0,85$;

In this case, $b=0,2 \mathrm{~m}$ for the case being considered, but in practice to construct drainage with $b=0,2 \mathrm{~m}$ is a complex process. Because excavators, which are used in practice in the course of excavation, do not allow the boulder to be measured.

We use the following approach to increase flow velocity in the drainage. If density increases by 20 percent without changing other parameters, the slope varies from $\mathrm{i}=0,00048$ to $i=0,0006$. When we calculate the hydraulic calculation of $b=1 \mathrm{~m}$ to $b=0,7 \mathrm{~m}$ by decreasing the width of the riverbed by $30 \%$ we can achieve water velocity from $\vartheta=0,25 \mathrm{~m} / \mathrm{s}$ to $\vartheta=0,27$ $\mathrm{m} / \mathrm{s}$. Excavation costs are reduced by $4.5-5 \%$, while the sparse consumption is declining. The results of the calculation are given in the following table. 
Table 4. Hydraulic elements of open horizontal drainage.

\begin{tabular}{|c|c|c|c|c|c|c|c|c|c|c|}
\hline \multirow{2}{*}{ 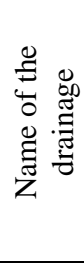 } & \multicolumn{2}{|c|}{ 选 } & 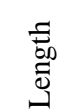 & 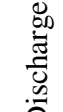 & 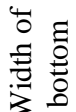 & $\frac{\ddot{0}}{n}$ & 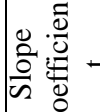 & 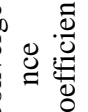 & 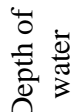 & 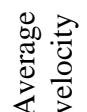 \\
\hline & $\begin{array}{c}\text { Beginn } \\
\text { ing of } \\
\text { PC }\end{array}$ & $\begin{array}{c}\text { End of } \\
\text { PC }\end{array}$ & $\mathrm{L}, \mathrm{m}$ & $\begin{array}{c}\mathrm{Q}, \\
\mathrm{m}^{3} / \mathrm{s}\end{array}$ & $\mathrm{b}, \mathrm{m}$ & $\mathrm{i}$ & $\mathrm{m}$ & $\mathrm{n}$ & $\mathrm{H}$ & \\
\hline 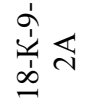 & $0+00$ & $14+00$ & 1400 & 0,1 & 0,7 & $\begin{array}{c}0,000 \\
6\end{array}$ & 1,75 & 0,03 & 0,30 & 0,27 \\
\hline
\end{tabular}

In the vegetation and noveggation periods, due to irrigation, the loading of the drainage is variable, ie discharge of water. Water with $3000-5000 \mathrm{~m} 3 /$ hectare volume which give to the field for salt washing in nonvegetation period and sewerage water waters during the vegetation period, changes in the level of groundwater flows, changes volume of flow in drainage at various times will result in considering the variation in current flow rates in the drainage, we can see the following table and figure (2) for the increase in the flow velocity by increasing the depth of open slopes in the section up to $\mathrm{h}=0.5 \mathrm{~m}$, (Table 5, Fig.6).

Table 5. The flow velocity in open beds corresponds to the depths

\begin{tabular}{|c|c|c|}
\hline $\mathrm{h}, \mathrm{m}$ & $\vartheta_{1}, \mathrm{~m} / \mathrm{s}$ & $\vartheta_{2, \mathrm{~m} / \mathrm{s}}$ \\
\hline 0 & 0 & 0 \\
\hline 0,1 & 0,14 & 0,15 \\
\hline 0,2 & 0,21 & 0,22 \\
\hline 0,3 & 0,26 & 0,27 \\
\hline 0,4 & 0,30 & 0,32 \\
\hline 0,5 & 0,34 & 0,36 \\
\hline
\end{tabular}

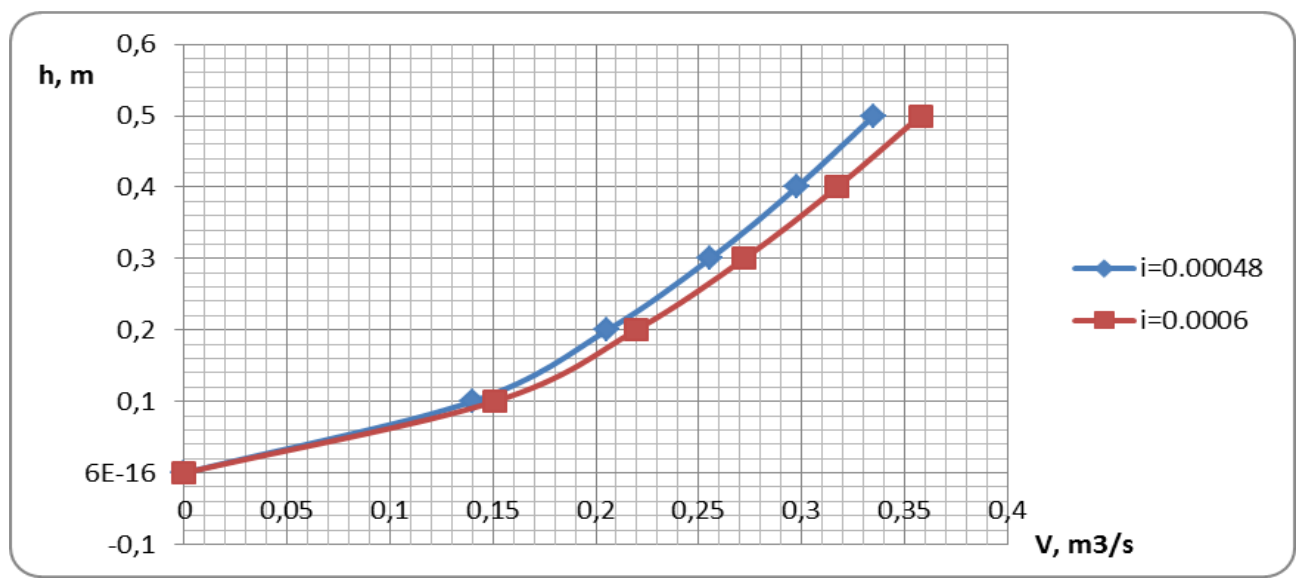

Fig. 6. A graph showing the flow velocity increasing according to flow depth . 
The analysis of calculated results suggests that the $20 \%$ increase in the flow rate brings to increase by $7-8 \%$ flow velocity. This results increases the sediment transportation property of the stream.

It is important to note that the sediment transportation ability of the flow is one of the main factors to provide dynamic stability of drainage system. By some scientists done scientific research on the formula for determining the sediment transportation of the stream. During the researches, the formula for determining the capability of flow has been improved. Taking into consideration the sediment transportation of the flow and the different fraction of sediments with different dimensions, we consider the following formula proposed by Professor A.M.Arifjanov [10,21].

$$
S=\alpha \frac{\vartheta^{3}}{g \cdot R \cdot \bar{W}}
$$

there: S-transportability of flow, $\mathrm{kg} / \mathrm{m} 3$;

$$
\begin{aligned}
& \alpha=\left(\frac{d_{0}}{d_{1}}\right)^{3} \text { - coefficient Arifjanov; } \\
& \mathrm{d}_{0^{-}} \text {optimal diameter of sediment particles, which speed of it equal to the flow } \\
& \text { velocity, } \mathrm{mm} \text {; } \\
& \mathrm{d}_{1^{-}} \text {diameter of sediments in the flow, } \mathrm{mm} \text {; }
\end{aligned}
$$

Or:

$$
\begin{aligned}
& \alpha=\sqrt[4]{\frac{W_{0}}{-}}{ }^{3} \text { - coefficient Arifjanov; } \\
& W_{0}=0,069 \text { MM/c } \text { - optimal speed of sedimentation degree, } \mathrm{mm} / \mathrm{s} \\
& - \\
& W \text {-sedimentation speed, } \mathrm{mm} / \mathrm{s} ; \\
& \vartheta \text {-speed of flow, } \mathrm{m} / \mathrm{s} ; \\
& \text { g-gravitation index; } \\
& \text { R-hydraulic radius }
\end{aligned}
$$

As on can see from the formula, the capacity of the flow increases depending on its velocity.

\section{Conclusions}

When designing the open drainage systems, it is recommended to take its smallest slope which $i=0,0003$. However, due to the natural field conditions, such kind of drainages with same slope, because of the low speed of water they fills with sediment in short times, as the results shape of cross-section changed, deteriorated. An example of this can be shown drainage system with name of VSh-20A, which is shown in Figure 3. The drainage is constructed with the a depth of $3 \mathrm{~m}$ on the ground floor, with a value of $i \leq 0,0003$. However, in the short time, the slope of the river has risen to 1.5 meters. In the ensuring dynamic stability of the drainage, the main focus should be on its slope to increase flow velocity. In order to avoid such negative situations, we recommend taking the smallest slope at $i>0,0005$ in the projection of the open drainage and applying it in practice.

The results show that the projection can increase the flow rate by $7-8 \%$ by increasing the slope rate of the explored drainage channel by $20 \%$, and as a result the flow efficiency can be up to $25 \%$. As a result, the dynamic density of the open drainages transportability increases by up to 25 per cent of good performance and efficiency which means that it has been added a year for 4 years to carry out periodic cleaning activities. If we look at the future for many years, we can save a lot of economical resources. 


\section{References}

1. Ahmedov H.A. Zax qochirish melioratsiyasi. [Stubble melioration]. O'qituvchi, Tashkent, 21 (2014)

2. Kostyakov A.N. Osnovi melioratsiy. [Fundamentals of melioration].Selxozgiz, Moscow, 535,536 P. (In Russian) (1938)

3. Averyanov S.F. Orositelniye melioratsii. [Irrigationamelioration]. Kolos, Moskov, 148,159 P. (In Russian) (1973)

4. Samoylov V.S., Levadniy V.S. Drenaj I ochistka stochnix vod [Drainage and wastewater treatment]. Adelant. Moskov, 45,48 P. (In Russian) (2009)

5. Zaydelman F.R. Melioratsiya pochv [Soil amelioration]. Moskov, 2003-45,48 P. (In Russian)

6. Babikov B.V. Gidrotenicheskiye melioratsiyii. [Hydrotechnical melioration]. SankPeterburg, 255,259 P. (In Russian) (2002)

7. Uzbekiston Respublikasi Prezidentining 2017 yil 7 fevraldagi PF-4947 sonliFarmoni [Decree of the President of the Republik of Uzbekistan from February 7, 2017 President's Decree No 4947]. (in uzbek) (2017)

8. Uzbekiston Respublikasi Prezidentining 2017 yil 27 noyabrdagi "2018-2019 yillarda irrigatsiyani rivojlantirish va sug'oriladigan yerlarning meliorativ kholatini yaxshilash buyicha Davlat dasturi" tugrisidagi PQ-3405 sonli qarori. [Decree of the President of the Republik of Uzbekistan "on the State Program on Development of irrigation and Improvement of irrigation irrigated Lands for 2018-2019" of November 27, 2017], No PD-3405. (in uzbek)

9. Syrdarya Regional Amelioration Expedition. Report. (2018)

10. Arifjanov A.M., Raximov Q.T., Xodjiyev A.K. Gidravlika. [Hydraulics]. O'qituvchi. Tashkent, 238, 243, 244, 254P (2016)

11. Arifjanov A.M., Fathulloev A.M.Dinamika vzvesenesushchego potoka $v$ ruslah.[Dynamics of a suspended flow in the channelsd]. Fan, Tashkent, 124 P. (In Russian) (2014)

12. Arifjanov AM, Fatkhullaev AM, Samiev LN, Ozandagi Jarayonlar va daryo cho'kindilari. [Processes in Uzgen and river sediments]. Monograph. The light of the publisher, Tashkent, 191P. (In Uzbek) (2017)

13. Arifjanov A.M. Metody raschota raspredeleniyachastitsnanosov $v$ ruslakh peremennogo secheniya [Methods for calculating the distribution of particles of sediment in the channels of variable cross-section]. Hydrotechnical Construction, Moscow, No4. Pp.50-54.(In Russian) (2014)

14. Arifjanov A. Raspredeleniye vzveshennykh nanosov v statsionarnom [Distribution of suspended sediment in the stationary flow].Water resources. Moscow, No2.Pp.185-187. (InRussian) (2011)

15. Arifjanov A.M., Usanov M.N. Kanallarda notekis xarakatning hususiyatlari [Peculiarities of uneven movement in the channels]. Journal "Agro ilm". Tashkent, No2. Pp.41-42. (In Uzbek) (2010)

16. Construction rulesan regulations. 06.03.97

17. Arifjanov A.M., Fatkhullaev A.M. Gidravlicheskiy raschet orositel'nykh kanalov v zemlyanom rusle [Hydraulic calculation of irrigation canals in the earthen channel]. 
Problems of agriculture and water management: Tez, Proc. scientific conf. 3-6 May. Tashkent, Pp. 66-67. (In Russian) (2004)

18. Arifjanov A.M.,Fatkhulloev A.M., Abduraimova D.A. Formirovaniye polya skorostey po glubine potoka $v$ orositel'nykh kanalakh[Formation of a velocity field along the depth of a stream in irrigation canals]. Actual problems of the natural sciences. Moscow, No5 (23). Pp . 397-399. (In Russian) (2013)

19. Arifjanov AM, Samiev L.N. Daryo cho'kindilarining fraksion tarkibini kimyoviy tarkibiga bog'liqligi [Depending on the chemical composition of the fractions of river sediments]. Journal "Irrigatsiya va melioratsiya". Tashkent, No2. (12). Pp. 34-38. (In Uzbek) (2018)

20. Arifjanov A.M., Samiev L.N., Ahmedov I.G. Irrigatsionnoe zhnachenie rechnykh nanosov [The irrigational value of river sediments.]. Actual Problems of Natural Sciences, Moscow, No06. (53). Pp.286-289. (In Russian) (2013)

21. Latipov K.Sh., Arifjanov A.M. Voprosy dvizheniya vzvesenesushchego potoka v ruslah [Questions of motion of suspended flow in the channels]. Mehnat, Tashkent, 110P. (In Russian) (1994) 